\title{
Kamila Żyło
}

Katedra Mediów i Kultury Audiowizualnej

Instytut Kultury Współczesnej

Uniwersytet Łódzki

\section{ŚWIAT WE MGLE I ŚWIAT ZA MGLA. EGZYSTENCJALIZM, REALIZM POETYCKI I AMERYKAŃSKI FILM NOIR}

The World in the Fog, the World behind the Fog. Existentialism, Poetic Realism and American Film Noir

\begin{abstract}
The main aim of the article is to depict similarities and differences between American film noir and French cinema of the 30s. I will, first of all, refer to the tendency of the prewar French cinema known as poetic realism as it constitutes the solid background for the film noir. But as my point is also to show that film noir roots can be found in other aspects of French culture, philosophical thought of Jean-Paul Sartre and Albert Camus (existentialism) will be discussed as well and presented as a kind of intellectual world view that links poetic realism and film noir.
\end{abstract}

Keywords: film noir, poetic realism, existentialism, film history, popular front cinema

Amerykański film noir okresu klasycznego jest obecnie nurtem szeroko opisanym w literaturze przedmiotu, nadal jednak pozostaje zjawiskiem wartym uwagi oraz wywołującym kontrowersje i spory wśród badaczy. Jednym z punktów skłaniających do dyskusji są jego korzenie, a więc źródła inspiracji, które ukształtowały oblicze kina czarnego. Lokują się one, jak w wypadku licznych artystycznych fenomenów, na styku wielu kultur, połączonych nie zawsze oczywistymi relacjami.

W wypadku amerykańskiego filmu noir źródeł inspiracji jest szczególnie wiele. Broniący jego specyficznie ,narodowego” charakteru badacze wskazują w tej kwestii na kluczową rolę prozy hard-boiled (przede wszystkim triumwiratu Raymond Chandler, James M. Cain, Dashiell Hammett) oraz wpływy amerykańskiego kina gangsterskiego lat 30. ${ }^{1}$ Szerzej patrzący na procesy kulturowe autorzy podejmują kwestię piętna, jakie na filmie noir odcisnęły romans gotycki, neorealizm włoski (przede

Zob. np. S. Faison, Existentialism, Film Noir and Hard-Boiled Fiction, Cambria Press, New York 2008; F. Hirsch, The Dark Side of the Screen: Film Noir, A.S. Barnes, San Diego 1981. 
wszystkim na tak zwanym semidocumentary noir $)^{2}$ czy psychoanaliza spod znaku Freuda, a nawet surrealizm ${ }^{3}$. Przede wszystkim jednak podkreślany jest związek tego nurtu z kinem niemieckim okresu Republiki Weimarskiej, zwłaszcza z filmem ekspresjonistycznym (miał on wpłynąć na sposób prezentowania sekwencji delirycznych koszmarów, jakich doświadczają bohaterowie), ale także miejskimi thrillerami Fritza Langa i tak zwanymi Straßenfilme $e^{4}$. Dominacja optyki „niemieckiej” w tym wypadku ma swoje źródła z jednej strony w definiowaniu filmu noir jako stylu (ten zaś faktycznie najbardziej przypomina styl filmów - uogólniając - „weimarskich”), z drugiej w niemieckiej afiliacji wielu jego czołowych twórców ${ }^{5}$. Badaczy kwestionujących to rozpowszechnione dziś przekonanie jest niewielu. Sceptyczny pozostaje np. Marc Vernet, który utrzymuje, że ekspresjonistyczny styl wizualny był częścią hollywoodzkich obrazów, zanim zrodził się film noir ${ }^{6}$, a Edward Dimendberg proponuje rozpatrywać film noir i kino weimarskie jako zjawiska stanowiące przejaw paralelnych modernizmów?

Dużo mniej rozpoznaną i rzadziej podnoszoną kwestią jest problem związków filmu noir z kulturą francuską. Zwłaszcza w polskim piśmiennictwie jest to temat właściwie nieobecny, choć niektórzy badacze uważają, że realizm poetycki wypełnił lukę między niemieckim ekspresjonizmem i amerykańskim filmem noir, a więc stanowił naturalne ogniwo w ewolucji pewnej tendencji. W moim przekonaniu szeroko pojęte kino niemieckie Republiki Weimarskiej wypracowało przede wszystkim (choć nie tylko) styl wizualny charakterystyczny potem dla kina noir, a realizm poetycki (lub bardziej ogólnie kino Frontu Ludowego) oraz francuski egzystencjalizm przyczyniły się do pogłębienia jego tematycznej i psychologicznej wymowy.

Celem niniejszego artykułu jest podjęcie próby wskazania pokrewieństw i różnic pomiędzy amerykańskim filmem czarnym a kinem francuskim lat 30. (zwłaszcza nurtem nazywanym realizmem poetyckim). Łącznikiem stanie się egzystencjalizm jako myśl, która stanowi w tym wypadku rodzaj światopoglądowo-ideowego zaplecza, przede wszystkim dla kina czarnego, ale która odcisnęła swoje piętno także na przedwojennym kinie francuskim, a z pewnością była odzwierciedleniem nastrojów panujących nad Sekwaną. Pisząc o egzystencjalizmie, będę się odwoływała głównie

Zob. ibidem.

3 Zob. np. J. Naremore, More Than Night: Film Noir in Its Contexts, University of California Press, Berkeley-Los Angeles-London 2008.

4 Więcej na ten temat: zob. A. Spicer, Film Noir, Pearson Education Limited, Essex 2002.

5 Czołowi reżyserzy amerykańskich filmów noir, tacy jak Robert Siodmak, William Dieterle, Fritz Lang, Otto Preminger, Edgar G. Ulmer, Rudolph Maté, byli niemieckimi emigrantami uciekającymi za ocean z powodów politycznych nastrojów w ojczyźnie albo emigrantami z Europy Środkowej i Wschodniej, którzy przez pewien czas pracowali w Berlinie, jak Billy Wilder czy Anatole Litvak.

6 Zob. M. Vernet, Film Noir on the Edge of Doom, w: J. Copjec (red.), Shades of Noir, Verso, London 1993, s. 1-32.

7 Zob. E. Dimendberg, Down These Seen Streets a Man Must Go: Siegfried Kracauer, Hollywood's Terror Films, and the Spatiality of Film Noir, „New German Critique” 2003, nr 89, s. 113-143. 
do kształtu, jaki nadali mu Jean-Paul Sartre i Albert Camus, odniosę się również do wpływu i recepcji ich myśli w Ameryce.

\section{Kręte ścieżki}

Termin noir - jak pisze Andrew Spicer - był stosowany przez francuskich krytyków oraz recenzentów już w latach 30., najczęściej w odniesieniu do nurtu, który teraz w historii kina określany jest mianem realizmu poetyckiego i obejmuje grupę filmów rozgrywających się w proletariackim środowisku, opowiadających historie o charakterze kryminalnym i romantycznym, kładących nacisk na atmosferę desperacji oraz akcentujących przeczucie nadchodzącej klęski ${ }^{8}$. Thomas Pillard wymienia 13 francuskich filmów powstałych w latach 1935-1939, określanych przez ówczesną krytykę jako noirowe. Są wśród nich przede wszystkim obrazy Marcela Carné z Jeanem Gabinem w roli głównej, ale także filmy Pierre'a Chenala, Jeana Renoira i Juliena Duviviera z tym samym aktorem9. Można więc skonstatować, ujmując problem szerzej, że przymiotnik ten odnoszono do filmów francuskich drugiej połowy lat 30 . o szczególnie pesymistycznym wydźwięku. James Naremore dodaje, że przed II wojną światową przymiotnika noir używała głównie francuska prasa prawicowa, kiedy chciała zganić niemoralność i skandalizujący charakter lewicowej kultury w ogóle ${ }^{10}$. Od początku zatem termin ten związany był z kulturą, a co więcej - stosowany w odniesieniu do sztuki filmowej. Teraz kojarzony jest przede wszystkim z kinem amerykańskim, a nie francuskim, ale jego najogólniejszy zasięg znaczeniowy nie uległ istotnej modyfikacji, choć nie ma już tak pejoratywnego wydźwięku.

Pojęcie noir do szerszego użycia wprowadzone zostało jednak dopiero po II wojnie światowej i to niemal jednocześnie w literaturze oraz filmie. Naremore pisze, że właśnie wtedy w Paryżu rozwinęła się noirowa wrażliwość (noir sensibility) ${ }^{11}$. Krytyk Nino Frank szybko dostrzegł pokrewieństwo pokazywanych wówczas w Paryżu amerykańskich filmów kryminalnych ${ }^{12}$ i ukuł termin ,film noir”, zapożyczając go

A. Spicer, op. cit., s. 15.

9 Owe 13 filmów to: Zbrodnia i kara (Crime et châtiment, 1935), reż. Pierre Chenal; Jenny (Jenny, 1936), reż. Marcel Carné; Ludzie z zaułka (Les Bas-fonds, 1936), reż. Jean Renoir; Pépé le Moko (Pépé le Moko, 1937), reż. Julien Duvivier; Le Puritain (1938), reż. Jeff Musso; Dziwny pan Victor (L'Étrange Monsieur Victor, 1938), reż. Jean Grémillon; Ludzie za mgła (Le quai des brumes, 1938), reż. Marcel Carné; Hotel du Nord (Hôtel du Nord, 1938), reż. Marcel Carné; Bestia ludzka (La Bête humaine, 1938), reż. Jean Renoir; La Tradition de minuit (1939), reż. Roger Richebé, Le dernier tournant (1939), reż. Pierre Chenal; Quartier sans soleil (zrealizowany w 1939, na ekranach w 1945), reż. Dimitri Kirsanoff; Brzask (Le jour se lève, 1939), reż. Marcel Carné. Zob. T. Pillard, Une histoire oubliée: la genèse française du terme «film noir» dans les années 1930 et ses implications transnationales, ,Transatlantica” 2012, vol. 1, nr 11, s. 3.

10 J. Naremore, op. cit., s. 15.

11 Ibidem, s. 11-12.

12 Uwaga krytyki skupiła się na pięciu filmach: Sokole maltańskim (The Maltese Falcon, 1941), Podwójnym ubezpieczeniu (Double Indemnity, 1944), Laurze (Laura, 1944), Żegnaj, laleczko (Murder, 
zresztą od nazwy serii francuskich przekładów amerykańskiej powieści hard-boiled tzw. Série noire. Po raz pierwszy określenie to pojawia się w jego artykule zatytułowanym Un nouveau genre ,policier”: L'aventure criminelle (Nowy rodzaj policyjnego dramatu: kryminat przygodowy) ${ }^{13}$ opublikowanym w sierpniu 1946 roku w lewicowym piśmie „L'Écran français”. Trzy miesiące później w bardziej konserwatywnym „La Revue du Cinéma” Jean-Pierre Chartier także podkreślał wspólnotę amerykańskich dzieł, dostrzegał, że są one przełomem retorycznym i tematycznym w kinie amerykańskim, ale ganił je za pesymizm i „wstręt do ludzkości” (ang. disgust for humanity). Amerykańskie filmy noir miały - jego zdaniem - nie wzbudzać w widzu współczucia i sympatii dla bohatera. Tytuł eseju brzmiał Les Américains aussi font des films „, noirs” (Amerykanie także [podkr. - K.Ż.] kręca filmy noir) ${ }^{14}$. W podobnym duchu wypowiadał się na łamach „La Nouvelle Critique” słynny George Sadoul, który dostrzegał w rodzącym się nurcie objaw upadku amerykańskiego społeczeństwa i przemysłu filmowego. Nino Franka w jego entuzjazmie dla amerykańskiego filmu noir wspierali z kolei lewicujący krytycy z „Positif”. Stanowiska były więc spolaryzowane, ale zjawisko i zmiana w kinie hollywoodzkim zostały odnotowane; odnotowane zostało także pokrewieństwo z rodzimym kinem realizmu poetyckiego.

Nie jest w tym kontekście sprawą przypadku, że to we Francji powstała pierwsza ekranizacja powieści Listonosz zawsze dzwoni dwa razy Jamesa M. Caina wyreżyserowana przez Pierre'a Chenala (Le dernier tournant, 1939). Amerykańskie kino noir sięgnie po tę książkę nieco później, ale dwukrotnie - w 1946 roku adaptacji dokona Tay Garnett, a w 1981 roku Bob Rafelson. Ponadto znaczący wydaje się fakt powstania noirowych remake'ów francuskich filmów z lat 30. Fritz Lang, kręcąc w 1945 roku Szkarłatna ulice (Scarlet Street), przypomniał pierwszy dźwiękowy film Jeana Renoira Suka (La Chienne, 1931). Klasyczny dla realizmu poetyckiego Brzask (1939) Marcela Carné z Jeanem Gabinem nakręcił ponownie Anatole Litvak - i zatytułował go Długa noc (The Long Night, 1947). Francuskiego gwiazdora w jego wersji zastąpił Henry Fonda. Bestia ludzka, powieść Emila Zoli rozgrywająca się w środowisku kolejarzy, najpierw zaadaptowana została przez Renoira (La Bête humaine, 1938), a potem znów przez Langa (Human Desire, 1954). Owe międzykontynentalne transfery pokazują wyraźnie, że amerykański film noir i kino francuskie lat 30. były sobie bliskie. Zainteresowania reżyserów koncentrowały się wokół podobnych tematów, wątków (przede wszystkim kryminalnych i melodramatycznych) oraz problemów, choć akcenty niejednokrotnie były rozkładane inaczej.

My Sweet, 1944) oraz Straconym weekendzie (The Lost Weekend, 1945), ale pokazano także takie obrazy jak Kobieta w oknie (The Woman in the Window, 1944), Listonosz zawsze dzwoni dwa razy (The Postman Always Rings Twice, 1946) i Obywatel Kane (Citizen Kane, 1941).

13 Przekład na język angielski: N. Frank, A New Kind of Police Drama: The Criminal Adventure, w: A. Silver, J. Ursini (red.), Film Noir Reader 2, Limelight, New York 2003, s. 15-19.

14 Zob. J. Naremore, op. cit., s. 13-14; oraz przekład na język angielski: J.P. Chartier, Americans Are Also Making Noir Films, w: Film Noir Reader 2, op. cit., s. 21-23. 


\section{Wpływy egzystencjalizmu}

Realizm poetycki i amerykańskie kino noir okresu klasycznego łączy przede wszystkim nasycenie pesymizmem, poczuciem braku nadziei na lepszą przyszłość, a także, choć w różnym stopniu, akcentowanie alienacji jednostki, chaosu i absurdu świata. Wartości te obecne są we francuskiej myśli egzystencjalnej. Bezpośredniość wpływu europejskiego egzystencjalizmu na klasyczne kino noir była po wielokroć stawiana pod znakiem zapytania. Stephen Faison zauważa, że myśl egzystencjalna w Stanach była właściwie nieznana w latach 40. i dopiero powojenna wizyta Sartre’a, Camusa i de Beauvoir zmieniła ten stan rzeczy, zwłaszcza że ich przybycie było nagłaśniane i komentowane przez prasę ${ }^{15}$. Środowisko intelektualistów przyjęło przybyszy i ich poglądy chłodno. Jak pisze George Cotkin, wielu z nich przyznawało, że:

egzystencjalizm uchwycił kondycję człowieka w ogóle, a dokładniej realia egzystencji w cieniu totalitarnej dominacji i możliwości atomowej anihilacji. Lecz ci sami intelektualiści dystansowali się od francuskiego egzystencjalizmu, ponieważ uważali sposób, w jaki Sartre i de Beauvoir podnosili temat zimnej wojny oraz ich literacką politykę, za naiwny i regresyjny ${ }^{16}$.

Padały zarzuty o promowanie mody na pesymizm zamiast przedstawiania filozoficznego stanowiska. Co więcej, sama myśl była sprzeczna z etosem amerykańskim opartym na wartościach pozytywnych i optymizmie. Zresztą USA nie miały powodu do pogrążania się w rezygnacji, bowiem kraj ten z wojny wyszedł zwycięsko i miał prawo widzieć przyszłość w jasnych barwach. Francja tymczasem była moralnie zdruzgotana i pogrążona w chaosie. Mimo stosunkowo późnej asymilacji europejskiego egzystencjalizmu na gruncie amerykańskim badacze wskazują na istnienie wcześniejszego, specyficznie amerykańskiego egzystencjalizmu. Strach, rozpacz, śmierć - zdaniem Cotkina - ukształtowały twórczość Jonathana Edwardsa, Hermana Melville'a, Emily Dickinson, Williama Jamesa, Edwarda Hoppera czy Waltera Lippmanna, a jako względnie skodyfikowany system filozoficzny egzystencjalizm został introdukowany w Stanach Zjednoczonych w latach 20., dzięki popularyzacji przez ministra Waltera Lowriego analiz myśli duńskiego egzystencjalisty Sørena Kierkegaarda ${ }^{17}$. Nie tyle więc w Ameryce istniał egzystencjalizm jako nurt czy szkoła filozoficzna, ile w myśleniu wielu twórców obecna była perspektywa egzystencjalna, wyznaczająca pewną postawę człowieka wobec świata. Różnica między amerykańską a europejską myślą egzystencjalną opierałaby się zaś na tym, że:

Amerykańscy egzystencjaliści nie zastąpili pesymizmu i rozpaczy europejskiego egzystencjalizmu optymizmem, ale też nie tarzali się z rozkoszą w jego desperacji. Odmówili uczynienia fetyszu z nihilizmu. W rękach Amerykanów (...) egzystencjalne podstawy cierpienia i rozpa-

\footnotetext{
15 S. Faison, op. cit., s. 1.

16 G. Cotkin, Existential America, The Johns Hopkins University Press, Baltimore-London 2003, s. 7.

17 Ibidem.
} 
czy funkcjonowały nie jako obezwładniające siły, ale jako bodźce do działania i rodzaj zobowiązania ${ }^{18}$.

W związku z tym amerykańska perspektywa egzystencjalna bliska była antynomizmowi, zakładającemu gotowość samotnej jednostki do wyrażania sprzeciwu wobec nakazów władzy w imię i w obronie swoich najgłębszych przekonań, a także odrzucającemu wszelką łatwą ,pewność” oferowaną przez skostniałe systemy religijne czy polityczne ${ }^{19}$. Rysem charakterystycznym amerykańskiej perspektywy egzystencjalnej jest więc dla Cotkina przede wszystkim wiara w niezbywalność i sensowność podjęcia działań, imperatyw akcji.

Podobne stanowisko zajmuje Faison, który twierdzi, że w gruncie rzeczy egzystencjalizm narodził się w Stanach przynajmniej o dekadę wcześniej niż w Europie i jest czymś w swej istocie odrębnym. W jego mniemaniu w duchu egzystencjalna, bowiem zawierająca elementy pesymizmu i realizmu, jest już proza Ernesta Hemingwaya i F. Scotta Fitzgeralda. O ile jednak w tym wydaniu można mówić o egzystencjalizmie klas wyższych, o tyle prawdziwe podwaliny pod amerykański egzystencjalizm zbudowała powstająca już w latach 20. proza hard-boiled fiction, która bohaterem uczyniła członka klasy pracującej i w dużej mierze ukształtowała kino noir. W obu tych zjawiskach amerykański egzystencjalizm objawił się zresztą w formie najpełniejszej, gdyż zarówno pisarze, jak i filmowcy wybrali perspektywę człowieka zwykłego, wywodzącego się ze społecznych nizin raczej niż high society, zaś jego postawa nie jest kwestią świadomego wyboru, lecz czymś, z czego zaczyna zdawać sobie sprawę, kiedy okoliczności zmuszają go do zastanowienia się nad własnym życiem²0. Amerykański egzystencjalizm w takim wydaniu zostaje pozbawiony zakorzenienia metafizycznego, gdyż:

W hard-boiled fiction i filmie noir doświadczanie nicości nie legitymuje się kosmicznym pochodzeniem ani nie odnosi się do kryzysu nowoczesnej filozofii, ale wyrasta z pustki skorumpowanego społeczeństwa. (...) Amerykański noir - zarówno jeśli chodzi o literaturę, jak i film - nie podejmuje próby udowodnienia prawdziwości tezy o izolacji jednostki w pozbawionym znaczenia, niedającym się wyjaśnić świecie natury ludzkiej egzystencji, ale oferuje przekonywającą wizję rzeczywistości, w której takie sytuacje są doświadczane przez bohaterów w konkretnych okolicznościach ${ }^{21}$.

Tym samym można więc mówić o perspektywie egzystencjalnej obecnej w amerykańskiej kulturze, zanim jej filozoficzne podstawy wyeksplikowali w swych rozważaniach francuscy myśliciele, gdyż filozoficzno-autobiograficzna powieść Mdłości Sartre'a została wydana w 1938 roku, a jego najważniejsza rozprawa filozoficzna Byt i nicość. Zarys ontologii fenomenologicznej w 1943.

Ibidem.

Ibidem, s. 8.

S. Faison, op. cit., s. 11.

Ibidem, s. 17. 


\section{Inne tropy...}

Filmowy realizm poetycki także poprzedza moment krystalizacji myśli egzystencjalnej na gruncie filozofii, choć jest nią już przesiąknięty. Jak pisze Krzysztof Trojanowski: „Wymowa, klimat i charakter realizmu poetyckiego doskonale trafiały w gust ówczesnej publiczności, coraz bardziej zaniepokojonej, zdezorientowanej i sfrustrowanej w przeczuciu nadciągającej katastrofy"22. Nurt zrodził się więc jako wynik społecznych przeczuć, w obliczu zagrożenia wojną. Gatunek noir w Stanach Zjednoczonych zainicjował nieco później, bo w 1941 roku, Sokót maltański (The Maltese Falcon) Johna Hustona. Stało się to w momencie, gdy w Europie wojna już trwała, lecz Ameryka dopiero zaczęła rozumieć i odczuwać prawdziwy jej wymiar, a kultura - jako barometr społecznych nastrojów - nań reagować. Oba nurty stanowiły zatem rodzaj papierka lakmusowego odzwierciedlającego sytuację polityczną i kryzys wartości moralnych. Na tym jednak analogie się nie kończą. Film noir stanowił, na co wskazuje choćby Paul Schrader ${ }^{23}$, spóźnioną odpowiedź kina na inny kryzys - ten ekonomiczny zainicjowany krachem na giełdzie w 1929 roku. Wielka depresja, odczuwalna także w Europie, stanowiła preludium narastającego poczucia zagrożenia i chaosu. Pogrążeni w biedzie, często bezrobotni bohaterowie filmów realizmu poetyckiego to jej ofiary. Dodatkowym czynnikiem podsycającym poczucie zagrożenia i niepewności w wypadku zarówno bohaterów filmów realizmu poetyckiego, jaki i kina noir była konieczność zmierzenia się z nowoczesnością, modernizacją, wielkomiejskim - przepełnionym licznymi niebezpieczeństwami, w tym rozluźnieniem więzi międzyludzkich oraz rosnącą przestępczością - stylem życia. Liczne czynniki społeczne, polityczne i ekonomiczne złożyły się więc na panujące nastroje oraz zainicjowały różnego rodzaju zjawiska w kulturze, $\mathrm{w}$ tym amerykański film noir i francuski realizm poetycki.

Należy także podkreślić literackie korzenie obu nurtów. O ile film noir czerpał z przywoływanej już prozy hard-boiled, której powieści - zwłaszcza początkowo były chętnie ekranizowane, o tyle sam termin „realizm poetycki” stosowany był najpierw przez krytykę literacką. Na grunt kina przeniósł go miłośnik dziesiątej muzy Michel Gorel, określając tym mianem film Pierre'a Chenala Ulica bez nazwy (La Rue sans nom, 1934) będący adaptacją powieści Marcela Aymé - pisarza książek dla dzieci i scenarzysty, łączącego realizm z fantastyką i satyrą 24 . Realizm poetycki, podobnie jak film noir, „formuje się więc (...) pod silnym wpływem literatury,

22 K. Trojanowski, W pułapce przeznaczenia. Realizm poetycki w „Hotelu du Nord” Marcela Carné, w: M. Jakubowska, T. Kłys, B. Stolarska (red.), Między słowem a obrazem, Rabid, Kraków 2005, s. 214.

23 P. Schrader, Uwagi o filmie noir, „Studia Filmoznawcze” 2010, nr 31, s. 71.

24 Do literatury pojęcie wprowadził Jean Paulhan, opisując nastrój powieści Marcela Aymé łączącej realizm i symbolizm. Zob. G. Stachówna, Francja lat trzydziestych: kino jako barometr, w: T. Lubelski, I. Sowińska, R. Syska(red.), Historia kina, t. 2: Kino klasyczne, Universitas, Kraków 2011, s. 166. 
głównie rodzimego populizmu, naturalizmu i fantastyki”"25. Warto jednak podkreślić inne „literackie powinowactwo”. Bestia ludzka Emila Zoli posiadająca - o czym była już mowa - swoją ekranizację zarówno noirową, jak i realistyczno-poetycką często określana jest mianem roman noir. Pojęcie to odnosi się do gatunku blisko związanego z prozą hard-boiled. W wypadku roman noir (inaczej noir fiction) głównym bohaterem nie jest jednak detektyw, a ofiara, podejrzany czy przestępca ${ }^{26}$. Pisarze spod znaku hard-boiled specjalizowali się zatem z jednej strony w powieściach detektywistycznych, z drugiej zaś - w tych spod znaku roman noir. Sam termin jednak, zanim Marcel Duhamel stworzył Série noire ${ }^{27}$ i odkrył pisarzy amerykańskich, odnoszony był do powieści kryminalnej, także tej XIX-wiecznej, a za francuskich jej prekursorów uznaje się - obok Zoli - także Honoriusza Balzaka (Tajemnicza sprawa, 1843) czy Eugène'a Sue (Tajemnice Paryża, 1942-1943). Wszelką prozę spod znaku noir, czy to amerykańską, za sprawą której roman noir stał się osobnym podgatunkiem, czy francuską, łączy przedstawianie świata pogrążonego w chaosie, tragiczny i pesymistyczny pogląd na rzeczywistość oraz społeczne zaangażowanie. Oczywiście jedna adaptacja powieści roman noir nie jest wystarczającym argumentem dla poparcia tezy o noirowości realizmu poetyckiego, choć stanowi ku temu przesłankę. Trzeba więc sięgnąć po inne argumenty.

Nazwa „realizm poetycki” do dziś budzi kontrowersje wśród filmoznawców (i nie tylko). Jedni wskazują, że jest to co prawda „paradoksalna zbitka słów”, jednak doskonale oddaje istotę zjawiska ${ }^{28}$. Inni stoją na stanowisku, że „Samotność tych postaci [bohaterów realizmu poetyckiego - przyp. K.Ż.], ich niezależność od kontekstu społecznego i epoki, ich fatalistyczna bezradność wobec zrządzeń losu były wręcz zaprzeczeniem realizmu"29. Bez względu na końcowy osąd nazwy nurtu zawsze podkreślany jest wspomniany fatalizm losów bohaterów. Jerzy Płażewski, odrzuciwszy tę niefortunną jego zdaniem ,etykietkę”, stosuje trafniejsze - w jego odczuciu - określenie i przemianowuje „realizm poetycki” na, nomen omen, „czarny romantyzm", tym samym intuicyjnie łącząc nurt z kategorią noir.

\section{Rozwidlająca się droga}

Pomimo licznych pokrewieństw genologicznych, podobnych czynników inicjujących narodziny obu nurtów oraz leżącej u ich podstawy myśli egzystencjalnej można wskazać znaczące różnice między amerykańskim filmem noir i francuskim

25 K. Trojanowski, op. cit., s. 213.

26 Zob. G. Tuttle, What Is Noir?, http://noirfiction.info/what.html (dostęp: 17.03.2015).

27 Warto dodać, że nazwę tę wymyślił Jacques Prévert, scenarzysta takich filmów jak Ludzie za mgła czy Brzask i jeden z głównych architektów sukcesu realizmu poetyckiego.

28 K. Trojanowski, op. cit., s. 214.

29 J. Płażewski, Historia filmu francuskiego 1895-2003, Oficyna Wydawnicza „Auriga”, Warszawa 2005, s. 125. 
realizmem poetyckim na poziomie konstrukcji fabuły, bohaterów, gatunkowych preferencji, wykorzystania stylistycznych środków wyrazu czy konkretnych rozwiązań narracyjnych. Wynikają one - ujmując rzecz najoględniej - z odmienności doświadczeń historycznych, generujących z kolei kulturowe i mentalne różnice między społeczeństwami.

Pierwsza zasadnicza różnica wiąże się z konstrukcją bohatera i sposobem, w jaki funkcjonuje on w otaczającej go rzeczywistości. Pisząc o egzystencjalizmie w amerykańskim wydaniu, podkreślałam znaczenie wprowadzenia bohatera z klasy pracującej. Kino realizmu poetyckiego operuje takim bohaterem w jeszcze większym stopniu. W Bestii ludzkiej jest on maszynistą, w Brzasku pracuje w fabryce, tytułowy Hotel du Nord w filmie Carnégo zamieszkują ludzie różnych zawodów należący do proletariatu, w Ludziach za mgła główny bohater jest dezerterem bez grosza przy duszy. Amerykański film noir portretuje raczej klasę średnią, niejednokrotnie borykającą się z finansowymi kłopotami, ale przede wszystkim posiadającą życiowe ambicje. Protagoniści filmu czarnego są wykonawcami wolnych zawodów (np. scenarzysta z Bulwaru Zachodzacego Słońca [Sunset Blvd., 1950]) lub pozwalających na pewną samodzielność (agenci ubezpieczeniowi w Zabójcach [The Killers, 1946] i Podwójnym ubezpieczeniu, prywatni detektywi w Sokole maltańskim i Wielkim śnie [The Big Sleep, 1946]). Liczną grupę stanowią także gangsterzy (Biały żar [White Heat, 1949]), wolne duchy (Listonosz zawsze dzwoni dwa razy [1946]). Co jednak ważniejsze, bez względu na aktualnie zajmowaną pozycję, są to ludzie walczący o własną niezależność i mocno stawiający na indywidualizm. Bohaterowie ci dążą do społecznego awansu (Mildred Pierce [1945]), pragną zawodowej realizacji, chcą podążać ścieżką sukcesu i móc postrzegać samych siebie jako self-made manów. Obie grupy łączy pesymistyczny pogląd na świat, rozczarowanie ładem społecznym, przekonanie o nieuchronności porażki.

Bohater realizmu poetyckiego ma twarz Jeana Gabina, o którym Płażewski pisze: „Symboliczna postać Jeana Gabina - którego szokującą wówczas plebejskość brano najczęściej zbyt serio - przedstawiała nie tyle robotnika, co robotnika rozczarowanego" ${ }^{30}$. Autor podkreśla, że był on posiadaczem ,proletariackiej powierzchowności, diametralnie różnej od landrynkowatych gogusiów, wszystkich tych «ulubieńców publiczności»: Henri Garatów i Pierre Richard-Willmów"31. Uosobieniem noirowego protagonisty był przede wszystkim niski i krępy, nieprzypominający hollywoodzkich amantów Humphrey Bogart, aktor o przeciętnej aparycji, ale ogromnej charyzmie i hipnotyzującym głosie. André Bazin pisał:

(...) nikt lepiej niż Bogart (...) nie ucieleśniał immanentności śmierci, a także zagrożenia śmiercią. Nie myślę o tej śmierci, którą się zadaje, ani o tej, którą się przyjmuje; myślę o śmierci z odroczeniem, która jest w każdym z nas. Jeśli jego śmierć tak bardzo, tak głęboko nas do-

30 J. Płażewski, op. cit., s. 134.

$31 \quad$ Ibidem, s. 125. 
tyka, to dlatego, że racją bytu jego życia była zdolność przetrwania. Śmierć święci więc w nim podwójny triumf, zwyciężyła nie tyle życie, ile odporność na śmierć ${ }^{32}$.

Dodaje także:

Człowieka bogartowskiego nie można określić doraźnym szacunkiem, jaki wzbudza, czy niechęcią wobec cnót mieszczańskich ani odwagą czy tchórzostwem. Można go określić jedynie dojrzałością egzystencji, dojrzałością, która nasyca powoli życie uporczywą ironią wobec śmierci ${ }^{33}$.

Bohaterowie realizmu poetyckiego przeczuwający własną klęskę, stojący w jej obliczu, pozostawali bierni i bezradni, pogodzeni ze swoim losem i nie stawiający mu oporu. Ich postawę charakteryzuje pogodzenie z nieuchronnym fatum i zgoda na śmierć, często wręcz świadomy jej wybór. Kochankowie przybywają do Hotelu du Nord, aby wspólnie popełnić samobójstwo, François w Brzasku całą noc snuje refleksje nad swoim losem, a rankiem odbiera sobie życie. Lantier w Bestii ludzkiej niezdolny zaakceptować tego, co zrobił, i własnej natury, wyskakuje z pociągu. Rozstanie z życiem jest dla nich jedynym sposobem poradzenia sobie z egzystencjalnym niepokojem i absurdem świata. W Hotelu du Nord Pierre powie do Renée, że mógłby się dopuścić zbrodni dla ich miłości - nie robi tego jednak i ma świadomość, że była to tylko czysta hipoteza. Ponadto, choć posiada skłonności psychotyczne i w napadzie szału dopuszcza się najcięższych zbrodni, nie potrafi odebrać człowiekowi życia z premedytacją. W Ludziach za mgła bohater morduje w przypływie emocji, w sytuacji zagrożenia, jednak gdy ochłonie, jak inni pozostaje bierny, wybiera ucieczkę, zmianę tożsamości, rozstanie z ukochaną.

Bohaterowie filmów noir postępują zgoła odmiennie. Ich pesymizm jest czynny. Wielu z nich podejmuje działania skrajne, mające zaradzić absurdowi świata, wyrwać ich z jego chaosu. Świadomie dopuszczają się zbrodni, oszustw, szantażu, niektórzy nawet je planują. Dobrowolnie wchodzą na drogę przestępstwa i podejmują niebezpieczną grę z losem, upatrując w tym jedynej szansy na odmianę własnej przyszłości. Samobójstwo czy bierne trwanie w marazmie nie jest dla nich rozwiązaniem. Dają się zazwyczaj ponieść ambicjom i namiętnościom, do końca walczą o własny los, nawet jeśli walka ta nie jest czysta i wymaga moralnie niejednoznacznych decyzji, a na szali trzeba postawić życie lub wolność. O ile niewinności i moralności protagonistów realizmu poetyckiego nie sposób zanegować, o tyle postaci zaludniające filmy noir balansują na granicy dobra i zła. Amerykańskie kino w latach 40. i 50. pokazywało wizję świata, „w której występek jest normą, a deprawacja punktem wyjścia”34, zaś w ich obliczu bohater nie pozostaje krystalicznie czysty, dokonuje wątpliwych wyborów, lecz działa, zamiast bezczynnie tkwić w martwym punkcie. Na ogół rzuca

32 A. Bazin, Śmierć Humphreya Bogarta, przeł. B. Michałek, w: idem, Film i rzeczywistość, Wydawnictwa Artystyczne i Filmowe, Warszawa 1963, s. 138.

33 Ibidem, s. 142.

34 B. Hrapkowicz, Kino wciąż jest czarne, „Kino” 2015, nr 3, s. 8. 
on wyzwanie fatalizmowi losu, bierze go we własne ręce, lecz przypadek czy seria zbiegów okoliczności sprawiają, że - tak czy inaczej - nie udaje mu się umknąć przeznaczeniu. Walter Neff, Joe Gillis i wielu innych noirowych protagonistów pozbawionych zostaje złudzeń. Zostają z niczym, poza świadomością własnej klęski i absurdu świata. Cynizm i ironia, eksplikowane najwyraźniej za pomocą narracji z offu, są świadectwem dystansu do świata i jedyną bronią przeciw śmierci, chaosowi i pustce. Samobójstwo nie jest wyborem bohaterów, częściej decydują się na karkołomną walkę, a działanie nawet w obliczu nikłej szansy na sukces pozostaje dla nich imperatywem kategorycznym. W Brutalnej sile (Brute Force, 1947) Jules'a Dassina grupa osadzonych za błahe przewinienia organizuje, mimo świadomości braku możliwości powodzenia, brawurową ucieczkę z pilnie strzeżonego więzienia. W Zmartym $w$ chwili przybycia (D.O.A., 1950) Rudolpha Maté otruty księgowy, któremu pozostał tydzień życia, rozpoczyna poszukiwanie własnego mordercy. Jeśli więc w wypadku realizmu poetyckiego można mówić o pesymizmie biernym i realizmie społecznym (podnoszenie problemu biedy, bezrobocia, braku szans na godne życie we względnym dostatku), to film noir oferuje pesymizm czynny i - portretując bohaterów zdecydowanie mniej wyidealizowanych, moralnie niejednoznacznych - realizm psychologiczny.

W obu nurtach obserwujemy też odmienne podejście do kwestii miłości. Dla bohaterów filmów realizmu poetyckiego miłość ma wartość nadrzędną, jest dla nich ostoją i posiada moc ocalającą, daje nadzieję i trzyma przy życiu. Zbrodnia zaś jest tylko pokłosiem amour fou, jej skutkiem ubocznym. Jeśli bohaterowie zabijają, to w afekcie (jak protagoniści Brzasku czy Ludzi we mgle), zabijają zresztą tych, którzy stają na ich drodze do szczęścia, są zagrożeniem dla ukochanej osoby. Kochają natomiast zawsze szczerze, prawdziwie, dojrzale i czule. Żadna ze stron nie jest zdolna do zdrady, oszustwa czy gry pozorów. Życie Renée w Hotelu du Nord ma sens tylko u boku Pierre'a, na którego czeka i któremu wszystko wybacza, Jean w Ludziach we mgle odnajduje sens istnienia, gdy poznaje Nelly, a François głębokim uczuciem darzy tylko naiwną kwiaciarkę, choć uwikłany zostaje w związek z bardziej doświadczoną kobietą. Nawet Pépé le Moko, rozgarnięty i sprytny, choć niepozbawiony uroku gangster, szczerze i z wzajemnością zakochuje się w kabaretowej aktorce Gaby i dla niej opuszcza swoją kryjówkę, co kończy się tragicznie. Bohaterowie francuskiego kina lat 30. kochają romantycznie i lirycznie, miłość ta doprowadza ich do śmierci, ale zgodnie z melodramatycznym wzorcem wiemy, że będzie trwała wiecznie. W Ludziach za mgła Jean, umierając na rękach ukochanej, powie: „Pocałuj mnie... Szybko... Nie mamy czasu". Romantyczna miłość ma więc swój fatalistyczny wydźwięk, ale pozostaje wartością niezmienną, nienaruszalną, często jedyną pozytywną stroną życia bohaterów, którzy oddają się jej i dla niej poświęcają życie. Kochankowie są zdesperowani, ale wywołują nasze współczucie i sympatię, kibicujemy ich miłości, przeczuwając jej nieuchronny finał.

W filmie noir miłość to nie głębokie uczucie, lecz namiętność nie do opanowania. Przesiąknięta jest ona przede wszystkim seksualnym pożądaniem i aurą perwer- 
sji. Trudno tu mówić o wzajemnych uczuciach, zazwyczaj chodzi o jednostronne, świadomie podsycane przez drugą stronę pożądanie. Mniej wyidealizowani noirowi bohaterowie dają się ponieść instynktom, żądzom, pasjom - i to one doprowadzają do ich porażki. Istotnym czynnikiem jest zresztą nie tylko namiętność do kobiety, ale i namiętność do pieniędzy. Kluczową postacią jest często femme fatale (niekiedy homme fatale), zdradliwa i podstępna, ale i obłędnie kusząca, która - zdolna za sprawą swej urody i tajemniczości manipulować bohaterem - przesądza o jego losie. Romantyczna miłość w jej wydaniu jest grą pozorów, wykalkulowanym działaniem, sprawną operacją logistyczną. Ludzkie relacje są więc tylko i wyłącznie destrukcyjne. Nawet jeśli w noirowych filmach pojawia się good girl, to na ogół nie jest ona w stanie ocalić bohatera. Romantyczna miłość zdarza się, ale dominują stosunki o charakterze reifikującym. Joe Gillis w Bulwarze Zachodzacego Stońca spotyka Betty - młodą, naiwną, początkującą scenarzystkę, ale zostaje przy Normie Desmond, która uwodzi go może nie tyle swą urodą, co blaskiem pieniędzy i pozycją. W Podwójnym ubezpieczeniu Walter Neff poznaje uroczą i niewinną Lolę, pasierbicę swojej kochanki, jednak jest już za późno, by uczucie do dziewczyny cokolwiek zmieniło. Symboliczna wydaje się tu ostatnia scena, w której dochodzi do konfrontacji kochanków i wspólników w morderstwie. Zamiast miłosnych deklaracji typowych dla realizmu poetyckiego, Phyllis mówi Walterowi, że nigdy go nie kochała, aż do tego momentu - momentu, kiedy nie potrafi wystrzelić w jego kierunku drugiej kuli. Dochodzi do miłosnego uścisku, lecz przerywają go kolejne wystrzały, tym razem Neff celuje do kochanki i dwie kule przeszywają jej ciało. Podobnie jak Jean i Nelly, bohaterowie Podwójnego ubezpieczenia „nie mają czasu” na miłość, choć przyczyny są całkiem inne. Koniec końców dostrzegają ułudę uczucia, którym obdarzyli drugą osobę, a stając w obliczu samotności, pozbawieni jakichkolwiek złudzeń, przestają się karmić mrzonkami o wspólnym życiu.

W amerykańskim filmie noir wszelkie relacje międzyludzkie są destrukcyjne, pesymizm jest więc tu pogłębiany, zaś remedium na chaos świata i absurd egzystencji nie istnieje. Jedyne, co pozostaje, to liczyć na samego siebie. Realizm poetycki nie operował właściwie figurą kobiety fatalnej; jeśli nawet w filmach tych pojawiały się bohaterki o niejednoznacznych intencjach (Brzask, Hotel du Nord), to ich wysiłki były bezowocne w obliczu siły uczucia, jakim bohater darzył good girl.

W związku z powyższym inne też są stosowane środki warsztatowo-formalne czy rozwiązania narracyjne. W filmach obu nurtów przeplatają się najczęściej wątki kryminalne i melodramatyczne, choć ich wzajemna relacja kształtuje się odmiennie. W filmach noir okresu klasycznego z aktywnym, działającym bohaterem pierwszoplanowym związany jest wątek kryminalny, dominuje akcja. Historia miłosna może go zainicjować albo być weń wpleciona, niemniej jednak niepokój rodzi sytuacja wynikająca z przestępstwa, najczęściej morderstwa, a więc lęk pojawia się w obliczu śmierci i spraw ostatecznych. Stąd narratorami/bohaterami często są postaci już nieżyjące (Bulwar Zachodzącego Słońca) lub takie, których życie wisi na włosku (Martwy w chwili przybycia). W realizmie poetyckim rola dominująca przypada wy- 
darzeniom melodramatycznym, a fabuła koncentruje się na losach kochanków oraz stojących na przeszkodzie ich szczęściu okolicznościach. To niemożność uczuciowego spełnienia skłania do stawiania pytań o sens istnienia. Jak zauważa Foster Hirsch:

Inaczej niż w amerykańskim kinie noir, zarówno w Brzasku, jak i Ludziach we mgle, zbrodnia wydarza się niejako „na marginesie”, w przestrzeni negatywnej towarzyszącej rozważaniom bohaterów na temat miłości i sensu życia. W tych filozoficznych, mrocznych dramatach przestępstwo to alibi, ,przykrywka” dla ważniejszych egzystencjalnych kwestii, w które filmy te są zaangażowane ${ }^{35}$.

Wątek kryminalny jest więc zaledwie nieprzewidzianym, nieplanowanym rezultatem rozwoju sytuacji i niesprzyjających okoliczności. Inaczej rzecz ujmując, bohaterowie czują egzystencjalny niepokój i napięcie, zanim cokolwiek się wydarzy. Ich wątpliwości wyrażone są w dialogach, podlegają dyskusji jak w Hotelu du Nord (rozmowa kochanków przed planowanym samobójstwem) czy Ludziach za mgła (monolog napotkanego w barze malarza). W filmie noir egzystencjalny dramat to pokłosie konkretnej sytuacji i działań bohatera. Gabin grał - jak pisze Spicer - „outsiderów, romantycznych, lecz [już! - przyp. K.Ż.] owładniętych samodestrukcyjnymi skłonnościami”" ${ }^{\prime 36}$, Bogart zaś outsiderów, którzy dopiero w obliczu sytuacji mieli zrozumieć nieuniknioność własnej klęski lub bezradność wobec absurdu rzeczywistości. Zresztą w filmach realizmu poetyckiego niepokój zdają się odczuwać nie tylko protagoniści. Hirsch konkluduje:

Podczas gdy nieuchronność przeznaczenia w większości amerykańskich filmów noir jest lokalna i personalna, tu [w Ludziach we mgle - przyp. K.Ż.] przybiera większy wymiar. Zmęczony życiem dezerter wydaje się ucieleśniać zranionego ducha przedwojennej Francji, tak jak gangster, który go zabija, reprezentuje rodzący się faszyzm ${ }^{37}$.

W amerykańskim filmie noir nieuchronność przeznaczenia dotyczyła nie tylko jednostek, lecz wyłącznie poszczególne jednostki zdolne były dostrzec absurd świata i aksjologiczną pustkę, w której żyło całe społeczeństwo. Filmy realizmu poetyckiego określano jako films de milieu (filmy środowiskowe) czy films d'atmosphère (filmy z klimatem), a nawet le fantastique social (fantastyka społeczna), amerykańskie kino noir skupiało się natomiast na bohaterze jednostkowym, wyalienowanym, opuszczonym i osaczonym, który w obliczu zbrodni - jakiej najczęściej dokonuje dla niekochającej go, lecz manipulującej nim kobiety - pozostaje z niczym poza poczuciem utraty sensu istnienia. $\mathrm{W}$ obu wypadkach pojawiały się elementy filmu gangsterskiego lub obraz szemranego półświatka. O ile jednak w kinie noir ów świat przesiąknięty jest deprawacją i często staje się symbolem obłędu, jaki ogarnął pozbawioną hierarchii wartości rzeczywistość en bloc, o tyle w realizmie poetyckim

35 F. Hirsch, Detours and Lost Highways: A Map of Neo-Noir, Limelight Editions, New York 1999, s. 72 .

36 A. Spicer, op. cit., s. 16.

37 F. Hirsch, op. cit., s. 72. 
gangsterzy to niekoniecznie szaleńcy (jak na przykład w Białym żarze), lecz ludzie wzbudzający sympatię widza (Pepé le Moko) albo znajdujący u niego, przynajmniej częściowe, zrozumienie; tajemniczy, lecz nie do końca negatywni (pan Raymond i Raymond w Hotelu du Nord czy Clara w Brzasku).

Pesymizm amerykańskiego nurtu pogłębiały często wykorzystywane rozwiązania narracyjne takie jak układ retrospekcyjny czy voice-over. Zabiegi te jednoznacznie uprzywilejowywały przeszłość. Wydarzenia, o których opowiadały filmy, miały często charakter dokonany, a więc nieodwracalny. Los już się dopełnił, przeznaczenie zrealizowało, a fatalizm zatriumfował. Obrazy realizmu poetyckiego na ogół (poza Brzaskiem) posiadają narrację linearną, a pesymizm mającego nastąpić rozstrzygnięcia awizowany jest jedynie na poziomie fabuły, przez co ma charakter mniej radykalny. Ludzi we mgle rozpoczyna scena samochodowego wypadku, w której główny bohater nie dopuszcza do potrącenia na szosie psa, krótko potem znika napotkany przez niego w barze malarz, najprawdopodobniej decydujący się na samobójczą śmierć. Próba jej dokonania otwiera także - o czym była już mowa - Hotel du Nord.

Ponadto realizm poetycki cechuje liryzm, w filmach tych poezja i tajemnica zaklęte zostają w otaczającej bohaterów codziennej rzeczywistości, służą temu zresztą odmienne niż w kinie noir środki filmowego wyrazu. Ujęcia są długie i często operuje się szerokimi, otwartymi planami, ruchy kamery są spokojne i miarowe, a przekadrowania są używane częściej niż gwałtowniejsze i bardziej dynamiczne cięcia, budujące napięcie i popularne w amerykańskim kinie czarnym. Kadry filmów noir często miały kompozycję zamkniętą, niekiedy acentryczną, dominowały plany wąskie i linie diagonalne, co doskonale oddawało sytuację bezwyjściowości, w której znajdował się bohater. Inaczej pracowano też ze światłem. Operatorzy realizmu poetyckiego, z których wielu przybyło z Niemiec, gdzie szlifowali swój warsztat, stosowali tu bardziej miękkie światło niż w weimarskich obrazach (a potem filmach noir) i nie wykorzystywali tak radykalnego światłocienia. Spicer podkreśla, że realizm poetycki stanowił modyfikację niemieckiego ekspresjonizmu, gdyż stawiał na budowanie rzeczywistości przesiąkniętej klimatem liryzmu ${ }^{38}$. Oczywiście, podobnie jak w ekspresjonizmie i kinie noir odnajdziemy np. w Ludziach we mgle ujęcia pełne lśniących od deszczu bruków i blasku neonów, ale zostaną one znacząco stonowane, rozpłyną się we mgle i dyskretnym światłocieniu budującym aurę zadumy, kontemplacji, poczucie fatalizmu odchodzących w dal postaci.

Podsumowując, w klasycznym filmie noir silnie wybrzmiewa egzystencjalne przekonanie o tym, że ,człowiek człowiekowi wilkiem”, co jest rezultatem między innymi tego, że kultura amerykańska jest bardziej nastawiona na indywidualizm, skupiona na jednostce oraz promuje aktywność i niezależność. W realizmie poetyckim dominuje z kolei fatalizm i poczucie nieuniknioności przeznaczenia. Być może takie społeczne odczucia, oddawane przez kino, były pokłosiem doświadczeń czasu I wojny światowej. Warto także pamiętać, że realizm poetycki to nurt, który narodził

38 A. Spicer, op. cit., s. 15. 
się, zanim II wojna światowa na dobre rozwiała wiarę w moralność człowieka, a humanizm i humanitarne wartości zostały bezprecedensowo zakwestionowane. Dlatego właśnie bohaterowie tego kina błądzą jeszcze w gęstniejącej mgle - stanowiącej symbol chaosu, absurdu, niepokoju - zaś noirowi protagoniści, straciwszy złudzenia, znajdują się za mgłą, która zdołała całkowicie spowić ich świat, przeniknąć dusze i pozbawić ich moralnego kręgosłupa. Ci pierwsi, jeszcze naiwnie i bezradnie przyglądają się rzeczywistości, ci drudzy wiedzą, że pozostała tylko desperacka walka. Francuski krytyk Jean-Pierre Chartier dostrzegał pesymizm obu nurtów, jednak noirowych bohaterów uznawał za potwory, kryminalistów, ludzi chorych, przepełnionych wewnętrznym zmysłem zła, a całemu nurtowi zarzucał antyhumanizm i perwersyjność konstrukcji fabularnych ${ }^{39}$. Czy jednak w świecie za mgłą pozostaje miejsce na coś innego?

\section{Bibliografia}

Bazin A., Śmierć Humphreya Bogarta, w: idem, Film i rzeczywistość, przeł. B. Michałek, Wydawnictwa Artystyczne i Filmowe, Warszawa 1963.

Chartier J.P., Americans Are Also Making Noir Films, w: A. Silver, J. Ursini (red.), Film Noir Reader 2, Limelight Editions, New York 2003.

Cotkin G., Existential America, The Johns Hopkins University Press, Baltimore-London 2003.

Dimendberg E., Down These Seen Streets a Man Must Go: Siegfried Kracauer, Hollywood's Terror Films, and the Spatiality of Film Noir, „New German Critique” 2003, nr 89, s. 113-143.

Faison S., Existentialism, Film Noir and Hard-Boiled Fiction, Cambria Press, New York 2008. Hirsch F., Detours and Lost Highways: A Map of Neo-Noir, Limelight Editions, New York 1999.

Hirsch F., The Dark Side of the Screen: Film Noir, A.S. Barnes, San Diego 1981.

Hrapkowicz B., Kino wciaż jest czarne, „Kino” 2015, nr 3.

Naremore J., More Than Night: Film Noir in Its Contexts, University of California Press, Berkeley-Los Angeles-London 2008.

Nino F., A New Kind of Police Drama: The Criminal Adventure, w: A. Silver, J. Ursini (red.), Film Noir Reader 2, Limelight, New York 2003, s. 15-19.

Palmer Barton R., Hollywood's Dark Cinema: The American Film Noir, Twayne Publishers, London-Mexico City-New Delhi-Singapore-Sydney-Toronto 1994.

Pillard T., Une histoire oubliée: la genèse française du terme «film noir» dans les années 1930 et ses implications transnationales, „Transatlantica” 2012, vol. 1, nr 11.

Płażewski J., Historia filmu francuskiego 1895-2003, Oficyna Wydawnicza „Auriga”, Warszawa 2005.

Schrader P., Uwagi o filmie noir, „Studia Filmoznawcze” 2010, nr 31.

Spicer A., Film Noir, Pearson Education Limited, Essex 2002.

39 Zob. R. Barton Palmer, Hollywood's Dark Cinema: The American Film Noir, Twayne Publishers, London-Mexico City-New Delhi-Singapore-Sydney-Toronto 1994, s. 10. 
Stachówna G., Francja lat trzydziestych: kino jako barometr, w: T. Lubelski, I. Sowińska, R. Syska (red.), Historia kina, t. 2: Kino klasyczne, Universitas, Kraków 2011.

Trojanowski K., W pułapce przeznaczenia. Realizm poetycki w „Hotelu du Nord” Marcela Carné, w: M. Jakubowska, T. Kłys, B. Stolarska (red.), Między słowem a obrazem, Rabid, Kraków 2005.

Tuttle G., What Is Noir?, http://noirfiction.info/what.html (dostęp: 17.03.2015).

Vernet M., Film Noir on the Edge of Doom, w: J. Copjec (red.), Shades of Noir, Verso, London 1993, s. 1-32. 